University of Wollongong

Research Online

Faculty of Law, Humanities and the Arts Papers (Archive)

Faculty of Arts, Social Sciences \& Humanities

$1-1-2012$

Speech acts and performances of scientific citizenship: examining how scientists talk about therapeutic cloning

Nicola J. Marks

University of Wollongong, nicolam@uow.edu.au

Follow this and additional works at: https://ro.uow.edu.au/lhapapers

Part of the Arts and Humanities Commons, and the Law Commons

Research Online is the open access institutional repository for the University of Wollongong. For further information contact the UOW Library: research-pubs@uow.edu.au 


\title{
Speech acts and performances of scientific citizenship: examining how scientists talk about therapeutic cloning
}

\begin{abstract}
Scientists play an important role in framing public engagement with science. Their language can facilitate or impede particular interactions taking place with particular citizens: scientists' "speech acts" can "perform" different types of "scientific citizenship". This paper examines how scientists in Australia talked about therapeutic cloning during interviews and during the 2006 parliamentary debates on stem cell research. Some avoided complex labels, thereby facilitating public examination of this field. Others drew on language that only opens a space for publics to become educated, not to participate in a more meaningful way. Importantly, public utterances made by scientists here contrast with common international utterances: they did not focus on the therapeutic but the research promises of therapeutic cloning. Social scientists need to pay attention to the performative aspects of language in order to promote genuine citizen involvement in techno-science. Speech Act Theory is a useful analytical tool for this.
\end{abstract}

\section{Keywords}

speech, acts, performances, scientific, citizenship, examining, about, scientists, cloning, talk, therapeutic

\section{Disciplines}

Arts and Humanities | Law

\section{Publication Details}

Marks, N. J. (2012). Speech acts and performances of scientific citizenship: examining how scientists talk about therapeutic cloning. Public Understanding of Science, 23 (5), 494-510. 


\title{
Speech acts and performances of scientific citizenship; examining how scientists talk about therapeutic cloning
}

Nicola J Marks

University of Wollongong

Faculty of Arts

Australia

nicola_marks@uow.edu.au

\begin{abstract}
Scientists play an important role in framing public engagement with science. Their language can facilitate or impede particular interactions taking place with particular citizens: scientists" "speech acts" can "perform" different types of "scientific citizenship". This paper examines how scientists in Australia talked about therapeutic cloning during interviews and during the 2006 parliamentary debates on stem cell research. Some avoided complex labels, thereby facilitating public examination of this field. Others drew on language that only opens a space for publics to become educated, not to participate in a more meaningful way. Importantly, public utterances made by scientists here contrast with common international utterances: they did not focus on the therapeutic but the research promises of therapeutic cloning. Social scientists need to pay attention to the performative aspects of language in order to promote genuine citizen involvement in techno-science. Speech Act Theory is a useful analytical tool for this.
\end{abstract}

Key words: stem cells, cloning, speech act theory, performativity, scientific citizenship, public participation, Austin, Butler 


\section{Acknowledgements}

This research was funded by a Medical Research Council Studentship. I would like to thank my supervisors Sarah Parry, Wendy Faulkner and Veronica Van Heyningen for their help and support. A previous version of this paper was presented at an Asia Pacific STS Network workshop in Tokyo in September 2010. I thank participants for their helpful comments and the University of Wollongong conference support for enabling my attendance. Members of Brian Martin's writing group at the University of Wollongong as well as Sarah Sorial provided comments on earlier drafts. Great thanks to David Simpson for helpful discussions about SAT and comments on this paper. Thank you also to three anonymous referees and the editor for their helpful suggestions.

\section{Author bio}

Nicola is a Lecturer at the University of Wollongong, in Science and Technology Studies Programme. She received her PhD from the University of Edinburgh. Some of her research interests include public engagement in science, the sociology of scientific knowledge and social aspects of stem cell research, reproductive technologies, and medicine more broadly. 


\section{Speech acts and performances of scientific citizenship; examining how scientists talk about therapeutic cloning}

\section{Introduction: Engagement and scientific citizenship}

Scholars from the critical or constructivist Public Understanding of Science tradition (cPUS) have been calling for public engagement in science, including public shaping of research agendas ${ }^{1}$. These calls have been taken up unevenly by governments and other sponsors of science-public interactions (e.g. see Irwin, 2006; Hagendijk and Irwin, 2006; Felt et al., 2009; Kurath and Gisler, 2009). There is a therefore a need to continue investigating public engagement, in particular where some voices are marginalised, whilst others are given great authority.

To do this social scientists, following Irwin's call, have started to examine how "scientific citizens" are constituted -- that is which kind of person is constructed as appropriate for public discussions and/or decision-making about techno-science (Irwin, 2001: 15). For instance, some science-public event organisers are shown to specifically seek out "open-minded" and "innocent" members of the public, rather than those with established opinions (Irwin, 2006: 315; see also Evans and Plows, 2007; Lezaun and Soneryd, 2007). Others, through story-telling, encourage the participation of people with socially "situated knowledges" (e.g. Scott and Du Plessis, 2008). Engagement activities thus are framed in particular ways: they reproduce the institutional culture of those designing or implementing them (e.g. Bickerstaff et al., 2010; Braun and Schultz, 2010).

Many of these studies explore scientific citizenship by investigating who is/isn't encouraged to speak, or how the event is organised (e.g. Irwin, 2006; Kerr et al., 2007; Felt et al., 2009). Others examine the terms of reference of the consultation process and have found that the latter tend to lead to the dominance of those who frame risk in a narrow scientistic way, and to the exclusion of those who use broader definitions of risk that include social and cultural factors (e.g. Robins, 2001; Genus and Rogers-Hayden, 2005; Wynne, 2005; Goven, 2006; Schibeci and Harwood, 2007).

There are also a number of studies that focus more specifically on how language can be fundamental to the construction of scientific citizenship. They argue that particular 
utterances can bring into being particular social relations: they can "perform" scientific citizenship. For instance, depending on how science, doctors and expectations are described in the media, the patient/scientific citizen is given a role as a passive object for medical research, a consumer of science or an active fighter against his/her disease or the medical system (Horst, 2007). Burchell (2007), building on Gilbert and Mulkay (1984), also argues that scientists' language in public can serve a performative function by delegitimizing opponents, whose views are described as non-neutral and biased.

Here it is argued that Speech Act Theory (SAT) is a useful analytical tool for cPUS scholars interested in scientific citizenship. A core insight of SAT is that language serves not only to make true or false statements. Rather with language we can produce "speech acts" and, to paraphrase Austin (1962), we do things with words. The success of these acts does not depend on the truth content of the utterances, but on a range of other factors, related to the "total speech situation" (1962: 148-51). This connects with the cPUS concnern with how the framing of public engagement (including through language) can perform the act of, for instance, excluding certain people from participation. In particular Butler's (1997) development of Austin's work is particularly useful here since it offers a way of examining the micro-level of language use (including in public settings), but also how this is embedded in the macro-level of social contexts (including how some voices gain legitimacy above others).

To show the potential usefulness of SAT, this paper examines how scientists talk, and how this may affect public engagement. Because science-based worldviews tend to frame public discussions about techno-science, scientists are key in science-public interactions (e.g. Nelkin, 1975; Parry, 2009; Lysaght and Kerridge, 2010): they have high levels of recognised authority, that is high levels of "symbolic power" (Bourdieu, 1975; Bourdieu and Wacquant, 1992: 148). The focus here is on how scientists in the field of stem cell research (SCR) in Australia talked about the label "therapeutic cloning" whilst this technology was under moratorium there.

In what follows, section 2 discusses SAT and how it may be useful to cPUS studies. Section 3 provides some details about the background to SCR in Australia and about the data sources drawn upon here. In Section 4, scientists in Australia are shown to problematise both words in "therapeutic cloning" during interviews. This data is then used as a context to examine the language they drew upon during the 2006 parliamentary review of stem cell 
legislation. The final section discusses the potential of scientists' language to enable different types of scientific citizenship. It explores how these performances of citizenship may or may not be successful, or felicitous, in practice. It argues that SAT can help identify ways of promoting science-public interactions where citizens can better voice and explore their concerns, and potentially shape regulation.

\section{Speech acts and performances of citizenship}

Speech Act Theory (SAT) makes sense of how language can change the social world. It was first described by Austin (1962) in lectures published posthumously and was subsequently codified by one of his students, Searle (e.g. 1969). It addressed a problem faced by traditional philosophers of language who based their work on the truth conditions of statements and therefore struggled to analyse utterances such as "I bet you five dollars she'll win" or "I promise to come tomorrow" (see Levinson, 1983: 226-83; Mey, 2001: 92-126). Austin highlighted that statements are not always (true or false) descriptions -- what he called constatives -- but instead can correspond to actions (such as betting or promising) -- what he called "performatives". As such, he posited that utterances can "perform" different kinds of acts, and these are not limited by their grammatical form. For instance, not all utterances that look like descriptions are necessarily used to state facts (e.g. Austin, 1962: 6-11).

Considering the performativity of language is important for those interested in public engagement in science. Indeed, statements made during science-public encounters are not simple descriptions of reality, but can play (explicit or implicit) strategic roles (e.g. Mulkay, 1994; Parry, 2003). Whether particular statements are accepted by others and contribute to changes in the social world (e.g. legalizing an area of research) is not determined solely by their truth content, but by other factors that SAT can help elucidate (see below). The notion of performativity has been taken up by some cPUS scholars ${ }^{3}$, but only in broad terms (e.g. Burchell, 2007; Horst, 2007). It is argued here that SAT can enable a more specific approach: it offers a precise vocabulary to talk about the transformative power of language, and enables the micro-analysis of language used in public engagement to be connected, through an examination of "felicity conditions", with different potential actions and outcomes.

According to Austin, utterance can be studied on three levels: firstly, at the level of "locutionary act" (1962: 94-8) or act of saying, which corresponds to examining what is said; 
secondly, at the level of "illocutionary acts" (1962: 98-100), which correspond to what social action is performed through the speech act (e.g. ordering or promising). Thirdly, analysts can examine "perlocutionary acts", that is the intended or unintended effects speech acts have on listeners: an utterance by one person may cause another to act in/feel a particular way (1962: 101-3). This separation between the three different types of speech acts is very useful. Although it may be difficult in practice (e.g. Searle, 1968), analytically it is possible and enables more precision: the separation gives the opportunity to specify what kinds of acts are being performed, and by whom.

In the context of public engagement, a locutionary act such as "I will help educate members of the public so that they can then enter into rational debate about these issues" can perform an illocutionary act of promising (to educate the public). It may also cause the perlocutionary act of silencing those who feel insufficiently educated. If these kinds of utterances are dominant and frame public engagement, the only scientific citizens who can easily play a role in decision-making become scientists and some highly educated publics. The only form of participation open to other publics is to become more educated.

Importantly, these performative, unlike constatives, are not true or false, rather they are "felicitous" or "infelicitous"; that is, the effects only take place if the right conditions are present. Austin's initial list of "felicity conditions" (1962: 14-5, see also 15-38) is for very specific, ceremonial, speech acts. So when he concludes that all kinds of utterances can be performative (1962, especially 121-64, see also Levinson, 1983: 231), he needs broader conditions which take better account of the context of utterances -- the "total speech act in the total speech situation" (1962: 148-51). These include the authority of the speaker and the kinds of speech acts considered possible and acceptable: e.g., engagement is more easily shaped by those with recognised legitimacy and who speak in accepted ways ${ }^{4}$. So a key insight of Austin's work is that the use of language is never merely the expression of beliefs or a description of the world; to use language -- that is to participate in discourse -- is always to perform an act in a social space. Butler's reinterpretation of Austin's work is helpful to examine this in more detail.

Butler (1997) analyses a variety of speech acts in practice and specifically links these to power, identities and social context. She argues for an understanding of language as able to constitute people in particular ways -- for instance, hate speech can constitute people as subordinate to others. She draws on Derrida to highlight that the power (or force) of a 
performative does not simply emanate from the utterer and his/her intention, but from the context -- meaning what is already sayable and doable (Butler, 1997: especially 51, 133). She also draws on Bourdieu and his concept of habitus -- the sets of embodied norms that are so taken-for-granted that we usually fail to realise that they shape our behaviour (Butler, 1997: 134-5; Bourdieu, 1980). She thus draws our attention to the social context which shapes what speech acts can be performed and by whom.

In addition, Butler highlights the transformative power of speech: people can use speech in non-authorized ways, and change the realm of what is acceptable. For example, when African-American woman Rosa Parks refused to relinquish her bus seat to a white passenger in segregated Alabama, Butler argues she performed a speech act that changed what was doable and sayable (1997: 147-8) $)^{5}$. As such, speech acts can change the speech situation. So Butler provides us with a set of felicity conditions that encompass symbolic power of speakers, their relationships with active listeners and the norms of what is sayable and doable in particular contexts.

Given scientists' symbolic power, but also given the transformative ideals of cPUS, it is interesting to investigate scientists' speech acts and their performative dimensions. Studies from cPUS have looked at scientists' discourses and their interpretative regularities (e.g. Gilbert and Mulkay, 1984; Mulkay, 1994; 1996; Kerr et al., 1997; Parry, 2003; Burchell, 2007), but do not always take into account power relations and social norms (see Gieryn, 1982). SAT as discussed above is an analytically useful tool to further develop this work: it provides a mechanism to make sense of how scientists' utterances connect with broader social contexts and can explain how some acts are felicitous without needing to refer to truth content. In addition, by enabling a detailed understanding of the different sorts of speech acts, it not only highlights what forms of scientific citizenship these can perform, but also potential alternative ways of talking and performing citizenship. Whether the particular utterances investigated in this study succeed in changing social relations is beyond the remit of this paper as it would require following each utterance and how it is accepted or rejected by others. Nevertheless, because of the potential of these speech acts to bring about change, it is important to examine them.

\section{Therapeutic cloning, public engagement and scientists' speech acts}




\section{Background}

Australia has recently attempted to embrace more inclusive forms of public engagement. This has however been limited in practice, especially in controversial areas (e.g. Schibeci and Harwood, 2007; Katz et al., 2009). Stem cell research (SCR) has been the source of much debate and stem cell researchers have been important stakeholders during Australian public discussions of the regulation of embryo research and cloning (e.g. Robins, 2005; Harvey, 2005; 2008; Ankeny and Dodds, 2008; Lysaght and Kerridge, 2010). In 2002, legislation was put in place making research on embryos from IVF legal under strict guidelines (Research Involving Human Embryos Act, 2002) and the creation of embryos using cloning technologies, whether for research or reproduction ${ }^{6}$, illegal (Prohibition of Human Cloning Act, 2002). This instated a moratorium on therapeutic cloning. It was later lifted after a parliamentary review of the legislation -- the Lockhart Review. This lead to the Prohibition of Human Cloning for Reproduction and the Regulation of Human Embryo Research Amendment Act (2006), which maintained the ban on reproductive cloning.

Although therapeutic cloning was under moratorium in Australia in 2002-6, it was legal in other countries such as the UK. This permissive legislation was partly attributed to the successful severing of therapeutic from reproductive cloning (Parry, 2003). A key strategy was to rhetorically separate the two by avoiding the term "cloning" and replacing the label "therapeutic cloning" with "somatic cell nuclear transfer" (SCNT) or "cell nuclear replacement" (CNR). Similarly, in 2004, the International Society for Stem Cell Research (ISSCR) decided at its annual conference that "nuclear transfer" should be used in preference to "cloning". The term "therapeutic cloning" was seen as a "commercial" term with "negative connotations, "cloning" as not "accurate", and "therapeutic" as "misleading" (see ISSCR, 2004).

However, Kitzinger and Williams (2005: 734-5) have noted that when scientists talk in public they tend to use "therapeutic cloning" as, unlike SCNT, the label directly implies therapies. Indeed, therapeutic promise has been an important part of promoting embryonic stem cell research in general (Rubin, 2008). During the UK debates on stem cell research, proponents of SCNT were keen to emphasise its potential therapeutic applications (Parry, 2003), in particular the promise of creating patient-specific therapies from cloned cells. Similarly, the therapeutic potential of cloning technologies was emphasised in Australia in the lead up to the 2002 Acts on embryo research and cloning (Harvey, 2005: 130). It is 
therefore clear that choice of labels such as "therapeutic cloning" can be a key rhetorical strategy ${ }^{7}$.

Interviews with scientists show that, even though their views are diverse (Davies, 2008a), for most of them science communication or public engagement is an opportunity to educate the public (Kerr et al., 1997). Even for the minority of scientists who see a more active role for members of the public, contributions of the latter are seen as secondary to those of scientists (Young and Matthews, 2007) and scientific knowledge is put forward as the ultimate guide and arbiter in decision-making about science (Davies, 2008b). The dominance and widespread nature of these assumptions in interviews echoes the dominant scientistic framing of public engagement discussed above ${ }^{8}$. As such, it is interesting to examine how scientists talk during interviews and in more public settings, in particular since, as Michael and Brown (2000) show, scientists' accounts of engagement during interviews can constitute citizens in particular ways.

\section{Methodology}

The present analysis draws on three sets of data. One is from the semi-private ${ }^{9}$ context of indepth semi-structured interviews with 31 scientists which took place in 2004-5 during the moratorium on therapeutic cloning. Respondents worked in a range of sub-fields within SCR, were of different levels of seniority and were located both in academic and commercial research. They were recruited through e-mail. Some were first met at conferences but most were contacted "cold". They were identified through a combination of "purposive" and "snowball" sampling (Gobo, 2004). No financial incentives were offered. The second and third sets of data correspond to the written submissions made to the Lockhart Review and to Hansard transcripts of the related 2006 parliamentary debates. These data form part of a larger project examining how scientists talk about stem cell research and public engagement in the UK and Australia.

Some interviewees are the same, or work in the same institutions, as scientists who participated in the public debates. Due to the informed consent agreement negotiated with participants in this study, the public and private utterances of particular individuals cannot be directly compared. However, it is interesting to examine the overall contrasts between public and private utterances. Interviews provide space for respondents to justify particular speech 
acts they may choose to perform in public settings and to reflect on some of the norms that may shape their behaviour. It is not argued that the voices used during interviews are more authentic than in other settings (see Gilbert and Mulkay, 1984; Potter and Mulkay, 1985) ${ }^{10}$, but they provide us with interesting additional data to make sense of public utterances, in particular which kinds of speech acts are described as do-able, and which end up reproduced - or not -- in public ${ }^{11}$.

In the next section, the first two parts examine interview data where respondents discussed the controversial labels therapeutic cloning and SCNT. Some potential speech acts based on these discussions -- and which may be utilized in public -- are suggested, and their performative aspects highlighted. This analysis is then used as a context for the third part which examines actual speech acts used during public discussions. Speech acts are recognised as utterances that do not just describe a situation, but do something. They are further identified by using Austin's formula: illocutions can in principle be expressed in the form "in saying x [speaker] was doing y" and perlocutions in the form "by saying $\mathrm{x}$ [speaker] did y" (to listener) (see 1962: 122) ${ }^{12}$. The conditions necessary for these speech acts to be felicitous is examined in the concluding discussion.

\section{4. "Therapeutic cloning" or "somatic cell nuclear transfer"? The importance of labelling}

“Cloning”: opening-up or closing down discussions?

As suggested above, "therapeutic cloning" can be a useful rhetorical tool. Interviewees repeatedly commented upon this label. Some argued that SCNT was more appropriate and accurate, others disagreed. An immunologist working with stem cells suggested that it was necessary to change the label and no longer use the word "cloning" due to its connotations:

Ben $^{13}$ : The issue basically is people call it cloning, and it is therapeutic cloning, but my

God, all you've got to do is look at it from the science point of view and see what you're doing is taking a nucleus and putting it from one cell into another. It's much better to utilise the term nuclear transfer, because it is, it describes exactly what you're talking about and it's devoid of all the hype, and devoid of the association with the concept of cloning another human being, which is what basically what a lot of people get upset about the possibilities of. 
This quote is representative of many respondents. Ben was implying that "nuclear transfer" is more accurate. He specifically highlighted that this label could serve to distance this technology from reproductive cloning, thus preventing discussions from focussing on the potential "slippery slope" that some people see between therapeutic and reproductive cloning. It also helps to obscure the origin of the cells: the word "cloning" reminds us that the cells in question come from a particular donor, whose genome is to be reproduced. By contrast, the word "nuclear transfer" associates the technique with the laboratory, severing links to the bodies of the cell/egg donors (see Parry, 2003). The implication here is that public debates should focus on technical aspects and avoid raising all these concerns.

The label "cloning" was also seen as problematic by an adult stem cell researcher who argued that it refers to too many biological processes to be useful:

Julian: I think one issue, getting back to the public-science debate is the, some of the ambiguity of some of the terminology, $[\ldots]$ the word cloning $[\ldots]$ is unhelpful: you can clone a gene, you can clone a cell, you can clone a person. [...] the public doesn't understand. What they do understand is they don't want a whole lot of human clones walking up and down the main street and they get scared by that, so it's an easy thing for politicians to scare people. And scientists somehow need to use language carefully to not confuse the debate. (emphasis added)

Many respondents described the public as ignorant and in need of simple clear messages highlighting the promise of SCNT but not "muddying" debates -- as another scientist put it -with a confusing merger with reproductive cloning. There is a concern about others, politicians here, using non-neutral emotive language to scare people.

This kind of reasoning may lead scientists to use labels such as SCNT instead of cloning in public. Then, the locutionary act of saying for example "SCNT needs to be legalised" can perform the illocutionary act of advocating an apparently non-controversial technology. It can also perform the perlocutionary act of causing others to feel unable to raise issues regarding the link between reproductive and therapeutic cloning, and the potential effects on donors' bodies. This could perform scientific citizens as people who are easily confused and swayed by terminology and who need to be given simple facts so they do not raise any misplaced concerns. The only citizens who should be involved in decision-making here are scientists and a few rational/educated others. 
One informant took a different approach. Although she agreed that "cloning" is not a very accurate label for the process of nuclear transfer, she criticised the move to simply change its name:

Heidi: [People] are not against the word [cloning], they're against the technique to make children, so just because you call it nuclear transfer, they still should be against it, you're just saying they don't understand what you're talking about because nuclear transfer is meaningless. To me, that seems really stupid, why not just discuss the issue $[\ldots]$

Heidi argued that dissociating reproductive and therapeutic cloning by name would not help resolve any difficulties. She portrayed these discursive changes as tactics to avoid difficult conversations. She suggested that it was appropriate to talk about "therapeutic cloning" and consider the issues that this label raises. She painted public engagement as an opportunity to discuss any concerns members of the public may have. If Heidi's apparent view here is reflected in public, locutionary acts such as "let's discuss the issues around cloning" will be more common. These can perform the illocutionary act of calling for discussions of concerns relating to cloning, and the perlocutionary act of causing the public to feel welcome to participate. This performs citizens as people with valid concerns that need to be further explored.

\section{"Therapeutic" cloning? What can and can't be said in public}

Despite the common focus, in public, on therapeutic applications of nuclear transfer (see above), most interviewees described this technology's main potential to lie instead in basic research. Only one highlighted the potential of SCNT in creating patient-specific organs for therapy.

Philip, working on embryonic stem cells, criticised the label "therapeutic cloning":

Philip: [...] In the old days of the IVF debate in the UK there was an attempt to substitute the term pre-embryo, to substitute for embryo, in what's currently done in IVF. I think the trouble with therapeutic cloning is that it's a terminology that's not accurate. It's not in and of itself therapeutic, the only goal isn't therapy, it's also research. And it's not cloning in the sense that cloning means to make a new individual, it's really, if you look at it in a scientific light, as cellular reprogramming. So it's an 
experiment with cultured cells. I think if we can get that idea across, we'll have done a good job (emphasis added).

This quote is worthy of note on three accounts. First, although Philip drew a parallel between the rhetorical manoeuvrings during the current stem cell debates and those during the 1980s, he did not portray the contemporary changes in labels as strategic. Rather, and this is the second point of note, he placed himself and other stem cell researchers as neutral and objective advice providers (Kerr et al., 1997) in search of accuracy. Third Philip, like most respondents above, constructed public discussions as fora to get simple and accurate messages across; a scientist's role is to educate.

Many other researchers in Australia articulated this view that therapeutic cloning is unlikely to directly provide therapies. For instance, Ben described it as "cumbersome", "technically very difficult and impractical" and "a hell of a trick to do". Nevertheless, several scientists wanted to push for its legalisation because it was described as needed "for the research", even if it probably would not be a useful technology in the long run.

This highlights the divergence between what stem cell researchers talk about in the semiprivate context of interviews -- the research potential of SCNT -- and what may filter out to broader communities -- its therapeutic potential. One reason for this divergence can be found in the following account by Philip, on embryonic stem cell research in general (rather than specifically on cloned embryos). He was discussing the difficulty in explaining "as clearly as possible the science behind everything":

Philip: To give you an example, I think that actually in some ways one of the most important contributions of embryonic stem cells in particular will perhaps not come from their direct use in the clinic, but rather from their use as research tools [...] But it's quite difficult to explain to the public. It's much easier to explain to the public well this might one day make this person walk. (emphasis added)

Philip was commenting on the debates in the lead up to the 2002 legislation on SCR in Australia. The public is described as unlikely to possess sophisticated understandings of how science operates, and in need of receiving simple messages, including promises of therapy.

Another scientist who worked with adult stem cells also argued that the value of SCNT was more likely to be for research, rather than directly for therapy. Despite this, she argued that she would highlight therapies when talking in public. 
Rachel: I think it's like anything, you've got to say there's a problem, there's patients with..., and stem cell transfer may offer a therapy $[\ldots]$.

Rachel articulated less discomfort than Philip with the idea of emphasizing less likely therapeutic applications to the public.

These two interviews suggest that a likely public locutionary act about SCNT might be "stem cell transfer may offer a therapy". This can perform the illocutionary act of promoting, rather than explaining, science. It can also perform the perlocutionary act of giving false hope and preventing discussions of other, potentially better, routes to therapy and of whether research tool potential is a sufficient justification for this research to proceed. If this type of utterance dominates during public engagement, the only scientific citizens whose participation would be encouraged would be scientists', and their role would be to sell their work; members of the public just need to be placated with empty promises of therapy.

By contrast, an adult stem cell researcher argued that SCNT was "not necessary" given the promises of adult stem cells and suggested highlighting this in the upcoming public discussions.

\section{Public discussions about SCNT}

The way respondents talked in interviews about therapeutic cloning and how it should be presented in public is varied. This variety is echoed during the Lockhart Review. There are however some important overall differences between the two data sets. Firstly, it seems scientists were able to focus on the research rather than therapeutic promises, despite the concerns regarding public understanding expressed above. Secondly, they did not primarily replace "therapeutic cloning" with "SCNT", despite most scientists above criticising the former label.

Some public submissions written by scientists in support of SCNT highlighted its promise as a research tool that may have implications for therapies in the future. For example, the Australian Stem Cell Centre argued for "the use of somatic cell nuclear transfer (SCNT) as a means of deriving disease specific stem cells for research purposes under an ethical license regime" (Inquiry into legislative responses to recommendations of the Lockhart Review, 2006: submission no.63, emphasis added). They did not mention patient-specific therapies. Other submissions emphasised both research and therapeutic applications: "only by 
encouraging research with all forms of stem cells will benefits result to the community, both of a scientific and therapeutic nature" (submission no.1).

By contrast, a stem cell company specifically highlighted that "at present the best approach to generate patient or disease-specific stem cell lines for research and therapeutic applications remains through the use of SCNT using human eggs" (submission no.104). Similarly, a group of scientists from the Australian Stem Cell Centre highlighted the importance of SCNT in both treatment and research into a long list of diseases, adding that "SCNT also provides a potential route to generating immuno-compatible grafts for the clinical application of stem cell therapies." Nevertheless, they did strongly emphasise the research importance of these cells, as a "unique opportunity to examine such disease states" (Submission no.73).

When giving expert testimony to senators, scientists mainly focussed on the research tool promises of SCNT. For example:

It is likely [...] that the vast majority of initial gains from any type of embryonic stem cell research or cloning research will relate to models of disease $[\ldots]$ and that therapies are well and truly a long way off. (Official Committee Hansard, 20 October 2006:

CA14)

In addition, a representative of the stem cell company discussed above also focused on research as a worthy goal (Official Committee Hansard, 24 October 2006: CA4). This differs slightly from what was raised in their written submission, which focussed on more direct therapeutic applications.

A couple of scientists did highlight a potential "therapeutic cloning" scenario (Official Committee Hansard, 23 October 2006, CA50). In addition, the imminence of therapy was highlighted:

I will definitely be applying for a licence to go for SCNT, because that is a patientspecific therapy down the track. With the success we have in converting these cells into different lineages, the time is not far away. (Official Committee Hansard, 23 October 2006: CA45)

This kind of language is rare though in the context of parliamentary discussions. The overall focus was on research tool applications, which differs quite markedly from the language used publicly by scientists in the UK to promote therapeutic cloning (as a patient-specific therapy). 
In terms of labels, scientists constantly switched between "SCNT" and "therapeutic cloning". This indicates that concerns expressed about the misleading nature of the label "therapeutic" were addressed by explicitly discussing research applications, instead of lesslikely direct therapeutic applications. The problematic association with reproductive cloning raised by the use of the label "therapeutic cloning" was countered by explicitly supporting a continued ban on the former practice.

During these Australian public discussions, locutionary acts similar to "It is likely that $[\ldots]$ cloning research will relate to models of disease $[\ldots]$ and that therapies are well and truly a long way off" were common. These can perform the illocutionary acts of presenting diverse potential promises of SCR and diverting the focus away from direct therapies. They can perform the perlocutionary act of causing people to talk about the role of cloning technologies in basic research. These speech acts perform scientific citizens as publics capable of supporting cloning legislation, even if there is no direct promise of therapy. Importantly though, the target publics here are elites: they are members of parliament who will be voting on the legislation. So although this indicates a respect for non-scientists as capable scientific citizens, it is not clear that this respect would extend to other members of the public.

Based on the interview data, one could expect that most scientists' public utterances would focus on therapeutic promises and use the label SCNT. That this was not the case is interesting. It suggests that their speech acts are shaped at different levels and do not depend solely on what they put forwards as the best approach during interviews. This is further discussed below.

\section{Discussion and conclusions: Citizenship, felicity conditions and therapeutic cloning}

\section{Multiple speech acts}

The interview data here show that scientists working in SCR talked about therapeutic cloning in multiple ways. Most criticised the label "cloning" for being inaccurate and for making a link between "therapeutic" and "reproductive" cloning. Many argued that the more technical "somatic cell nuclear transfer" or "SCNT" should be used instead as it would prevent the public from becoming unduly worried. One scientist, by contrast, argued for the need to use the label that members of the public would understand (cloning), regardless of whether it may 
connect to controversial reproductive cloning. She argued for broader discussions with the public about their concerns. In parallel, most scientists indicated that therapeutic cloning may have more use as a research tool than directly in therapies. Some therefore criticised the use of the label "therapeutic" and suggested public debates should focus on the more promising research applications of the technology. A few scientists however discussed the need to focus on therapies in public in order to garner public support for research.

The common suggestions made during interviews regarding how one should talk about therapeutic cloning contrast with the language that was in fact used in public. Most scientists during the Lockhart Review did not avoid the label "therapeutic cloning". In addition, they did not focus their discussions (in writing or in person) on the therapeutic promises of this work, but on its research promises (there are of course a few exceptions as discussed above). This also contrasts with the usual focus on therapies during public debates in other countries highlighted in section 3.

Speech Act Theory, in particular Butler's reinterpretation of Austin's work, highlights that language choices can do things (like exclude potential participants in public engagement). It also highlights that the felicity or success of these speech acts is not connected solely to their truth content, and points instead to the importance of other factors, such as symbolic power. SAT thus enables us to analyse scientists' utterances in more depth at the micro-level by considering their potential performative aspects. It also permits these analyses to be connected to the macro-level by examining elements of the total speech situation. From this we can suggest preferable alternative speech acts and also make sense of the contrast between the public talk investigated here and other public talks as well as the interview data from this study. I now turn to this in more detail.

\section{Felicity conditions and performances of citizenship}

Based on what scientists discussed during their interviews, a number of potential locutionary acts that might be reproduced in public settings were put forward. These include "SCNT needs to be legalised", "Let's discuss the issues around cloning" and "This research will lead to therapy". Some illocutionary and perlocutionary acts these might perform were then drawn out. The former include advocating or selling therapeutic cloning, providing information and calling for inclusive discussions about public concerns; the latter include causing people to 
feel unable to discuss the link between therapeutic and reproductive cloning or the lack of therapeutic applications, and encouraging broad discussions about the issues surrounding this technology.

It was argued that, if these types of utterances were reproduced in public, they may encourage people to perform particular types of scientific citizens. For instance, if scientists are asked to speak in public contexts and keep repeating that "SCNT" must be legalised (rather than saying that there are issues around "therapeutic cloning" which need to be discussed), it is more difficult for a member of the public to interject, argue that SCNT is a confusing label and push for a discussion of the link between reproductive and therapeutic cloning. It is more likely that publics will take on a passive role: the technical labels help to exclude those who do not have a technical background. In the same way, putting forward an image of publics as uninformed and scientists as neutral information providers can create a reality where engagement becomes education and scientific citizens are only those who have been educated and accept a scientistic framing of the issues. By contrast, describing both publics and scientists as having relevant concerns can create a reality where engagement becomes respectful conversations between a diversity of scientific citizens who can challenge the usual scientistic framing of engagement.

Importantly, for these performatives to be "felicitous" (Austin, 1962) -- here this means for the suggested versions of scientific citizenship to be performed -- a number of conditions need to be fulfilled. To examine this, as discussed in section 2, we should pay attention to pre-existing and normalised ways of talking and acting, and to the symbolic power of those who are talking. To use Butler's words:

If a performative provisionally succeeds [...] [it is because] that action echoes prior actions, and accumulates the force of authority through the repetition or citation of a prior and authoritative set of practices. (1997: 51, original emphasis)

I have argued that the framing of public engagement tends to privilege scientistic worldviews; thus there exists an accepted set of practices whereby scientists tell others the best way to approach a scientific issue. As such, scientists by definition will have great epistemic authority; and their utterances are likely to be taken seriously.

In addition, a common and accepted role for scientists in public is to educate (e.g. Davies, 2008b). This explains why many scientists in this study portrayed themselves as providers of clear simple technical information (cf. Kerr et al., 1997) and made calls for 
education. It also means that taking on this role in public will be accepted as normal: seeing scientists as objective educators forms part of our habitual ways of thinking, and scientists are very much encultured to see themselves as such. This explains the evidence here that the deficit model of public understanding of science shapes many of these utterances. Most interviewees expressed the desire to simplify or clarify debates so that the public can better understand the facts, and not have irrational reactions. Few of them argued in favour of listening to other valid forms of understanding (similar to Davies, 2008a; Parry, 2009). So these scientists are not inventing the deficit model; they are replicating conventional ways of talking and doing (Wright and Nerlich, 2006; see also Kerr et al., 2007 ).

Therefore, the speech acts suggested from Heidi's interview data are unusual. By arguing for open conversations about public fears, she is breaking with the deficit model tradition. Similar to Rosa Parks' refusal to move (see section 2), the unconventional speech acts suggested by Heidi's interview could play a transformative role if reproduced in public settings. However, these may still need to be performed by the right kind of speaker in the right context: as Parks needed to be the right kind of person making a statement at the right time/place (Lovell, 2003), not everyone can challenge and transform the framing of public engagement at any time. Perhaps someone like Heidi with the symbolic power that comes from being a scientist speaking about science, in the context of an increased visibility of cPUS views, might be the right person for this potentially transformative speech act: she is more likely to change the habitual ways of organising public engagement than a citizens' group calling for the inclusion of their views.

However, a corollary to this is that scientists who leave their conventional role of neutral information providers risk their symbolic power. The status they gain by fitting their conventional role can be lost if they are perceived to take on a different one. To draw on a different example, scientists who want to effectively promote an area of research may need to rigorously maintain their non-partisan/rational stance and ways of talking. This echoes Lysaght and Kerridge's (2010) argument that being able to describe one's claims as "scientific" and "value-neutral" is an important rhetorical strategy to improve one's epistemological, but also moral authority. It indicates that scientists can make the authority they have in the scientific field relevant to the public engagement field, but they must be careful to maintain their expected role. In parallel, they must avoid being seen as acting in a strategic way: this can be more damaging to scientists -- because of their traditional role as neutral information-providers -- than other groups such as politicians. These struggles 
resemble those encountered by AIDS treatment activists attempting to transfer their authority between different fields (Epstein, 1996). This situation helps us make sense of the difficulty many scientists had with the idea of promoting areas of SCR by using language in explicit strategic ways (e.g. Philip).

The total speech situation does not only include the speaker and their symbolic power. The uptake of the message by listeners and the success of the speech acts will also depend on other social contexts. These can be particularly important here in explaining the apparent disconnect between the public talk that took place, and what might have been expected based on the interview data and on other public discussions. For instance, a crucial element of the total speech situation here is that, by the time of the Lockhart Review, several years had passed since the early promises regarding the therapeutic potential of cloning. In addition, these public discussions took place immediately after the initial claims by a laboratory in South Korea to have successfully derived patient specific cell lines were shown to be fraudulent (see Augoustinos et al., 2009 for an analysis of how this impacted on discussions in the media and the scientific community). So continuing to make wide-ranging claims about therapies when listeners know that these do not yet exist is difficult; in this changed context, the speech act of promising cures is no longer as doable and sayable (Butler, 1997) as previously (cf. Rubin, 2008) and performing it anyway risks making the speaker loose the epistemic authority that derives from being seen as neutral and objective.

In addition, there had been a shift in the public debate in Australia. The Lockhart Review took for granted that research on embryos should continue and it was constrained to focussing on how the economic and scientific development of Australia could be encouraged "by suggesting that restrictions be lessened and regulatory control be streamlined" (Harvey, 2008: 39). Thus the whole future of these scientists' field was not in jeopardy, as it may have seemed in the 2002 debates. As such there was no need to make extreme promises. This suggests the importance of considering whether a technology is emerging or established (see Brown and Michael, 2003) in shaping scientists' speech acts and their felicity (see also Burchell, 2007 who reminds us that scientists' language is shaped by the level of controversy surrounding the area they are talking about). This can also help explain why in Australia most interviewees found therapeutic cloning worth talking about. This contrasts to interviews undertaken in the UK at a similar date and where the change of labelling suggested by the ISSCR was not raised, presumably because the technology was already legalised (Marks, 
2008). These examples illustrate how scientists' talk is influenced by national policy and international as well as local social and scientific contexts.

\section{Transformative speech acts and further research}

The main focus of Australian public debates in 2006 was not on distant therapeutic promises, and the language used did not draw predominantly on technical labels that can mask ethical and social issues. SAT, by embedding utterances in broader social contexts can contribute towards a better understanding of this. In addition, it can help us find ways of fostering conversations where different parties feel they can speak openly, even when the future of a field may be under threat. I suggest that speakers with symbolic power recognised in the field of public engagement in science -- such as scientists -- can play a key part: they can take on a non-conventional role, advocate further public participation and challenge common scientistic framings of engagement.

The focus of this work on scientists should not lead us to overlook others however, especially those that may have felt excluded from these elitist parliamentary debates, which focussed on "technical", rather than "ethical" aspects of SCR (Harvey, 2008) -- that is, scientists' specialty. Further work should also explore in more detail how particular utterances and labels are accepted or challenged, and whether they do bring about tangible changes in the social world. It could additionally investigate how these speech acts and performances of citizenship fit into broader models of democracy and how they are shaped by public relations officers and other professional science communicators. It might also examine how the speech acts of particular individuals change in different temporal, geographical and social settings.

\section{Acknowledgements}

This research was funded by a Medical Research Council Studentship. I would like to thank my supervisors Sarah Parry, Wendy Faulkner and Veronica Van Heyningen for their help and support. A previous version of this paper was presented at an Asia Pacific STS Network workshop in Tokyo in September 2010. I thank participants for their helpful comments and the University of Wollongong conference support for enabling my attendance. Members of Brian Martin's writing group at the University of Wollongong as well as Sarah Sorial 


\section{provided comments on earlier drafts. Great thanks to David Simpson for helpful discussions}

about SAT and comments on this paper. Thank you also to three anonymous referees and the editor for their helpful suggestions.

\section{Notes}

\footnotetext{
${ }^{1}$ Some examples include Irwin (1995), Irwin and Wynne (1996), Epstein (1996), Collins and Evans (2002), Dietrich and Schibeci (2003), Braun and Schultz (2010) and Delgado et al. (2011).

${ }^{2}$ Therapeutic cloning is the creation of embryos from cells such as skin cells with the aim of deriving cell lines that immunologically match the patient who donated the skin cells. Other labels, e.g. somatic cell nuclear transfer, can also be used but, as will be discussed here, are not quite synonymous.

${ }^{3}$ Although see Szerszynski's (1999) critique of Wynne specifically for not attending to the performative dimensions of language.

${ }^{4}$ These are not features that have been picked up by all of Austin's followers. There are two schools of thought based on his work (Sbisà and Fabbri, 1980): one focussing on the speaker and their utterance, the other considering speech in their broader social context. The latter is drawn upon here, since the former is seen as too formalized and theoretical, and does not enable an account, or the possibility, of social change (see Streek, 1980; Mey, 2001 especially 320; Levinson, 1983, especially 240-2; Wood, 2011).

${ }^{5}$ See the conclusion for a development of this interpretation.

${ }^{6}$ Like therapeutic cloning, reproductive cloning involves creating an embryo from cells such as skin cells. However, in contrast to the former, the aim is to implant the embryo in a surrogate and create a live animal that is the genetic clone of the skin cell donor. This is how Dolly the sheep was created.

${ }^{7}$ Stem cell scientists' language choices are not always "merely strategic" though (see Hauskeller, 2005).

${ }^{8}$ This is not to say that scientists' language choices inescapably and uniquely constrain science-public interactions. In keeping with Butler's thesis, citizens can successfully resist the roles they are given (e.g. Epstein, 1995).

9 The term "semi-private" is used here to indicate that although interview data can relate to the way one person (the interviewee) relates to another (the interviewer), and therefore that interviews are not the same as data from public fora such as debates, they are not "culturally unique": interviews reflect dominant social and cultural norms (Kerr et al., 1998; see also Potter and Mulkay, 1985).

${ }^{10}$ In particular, the relationship established between interviewer and interviewee can shape the way they (both) communicate. Here some respondents initially came across as hostile and defensive, but used more conciliatory language once they realised the interviewer was not a journalist and had a background in science. It is impossible however to tell exactly how each respondent perceived the interviewer at different times during the interview.

${ }^{11}$ Following Kerr et al. (1997), and to use Gilbert and Mulkay's (1984) vocabulary, scientists' utterances are analysed here both as "topic" and "resource".

${ }^{12}$ Although Austin ultimately found this formula unsatisfactory (1962: 123-32), it is a useful guide in identifying speech acts.

${ }^{13}$ Pseudonyms are used here in accordance with the anonymity agreement reached with interviewees.
} 


\section{References}

Ankeny, R. and Dodds, S. (2008) "Hearing community voices: Public engagement in Australian human embryo research policy, 2005-2007", New Genetics and Society 27(3): 217-32.

Augoustinos, M., Russin, A. and LeCouteur, A. (2009) "Representations of the stemcell cloning fraud: From scientific breakthrough to managing the stake and interest of science", Public Understanding of Science 18(6): 687-703.

Austin, J.L. (1962) How to do things with words: The William James lectures delivered at Harvard University in 1955 Oxford: Clarendon Press.

Bickerstaff, K., et al. (2010) "Locating scientific citizenship: The institutional contexts and cultures of public engagement", Science, Technology, \& Human Values 35(4): 474-500.

Bourdieu, P. (1975) "The specificity of the scientific field and the social conditions of the progress of reason", Social Science Information 14: 19-47.

Bourdieu, P. (1980) Le sens pratique. Paris: Editions de Minuit.

Bourdieu, P. and Wacquant, L.J.D. (1992) An invitation to reflexive sociology. Oxford: Polity Press.

Braun, K. and Schultz, S. (2010) "'... A certain amount of engineering involved': Constructing the public in participatory governance arrangements", Public Understanding of Science 19(4): 403-19.

Brown, N. and Michael, M. (2003) "A sociology of expectations: Retrospecting prospects and prospecting retrospects", Technology Analysis and Strategic Management 15(1): 3-18.

Burchell, K. (2007) "Empiricist selves and contingent "others": The performative function of the discourse of scientists working in conditions of controversy", Public Understanding of Science 16(2): 145-62.

Butler, J. (1997) Excitable speech: A politics of the performative. New York: Routledge.

Collins, H.M. and Evans, R. (2002) "The third wave of science studies: Studies of expertise and experience", Social Studies of Science 32(2): 235-96.

Davies, S.R. (2008a) "'A bit more cautious, a bit more critical': Science and the public in scientists' talk" in Science and its publics, edited by A. R. Bell, S. R. Davies and F. Mellor Newcastle: Cambridge Scholars.

Davies, S.R. (2008b) "Constructing communication: Talking to scientists about talking to the public", Science Communication 29(4): 413-34.

Delgado, A., Lein Kjølberg, K. and Wickson, F. (2011) "Public engagement coming of age: From theory to practice in STS encounters with nanotechnology", Public Understanding of Science 20(6): 826-45.

Dietrich, H. and Schibeci, R. (2003) "Beyond public perceptions of gene technology: Community participation in public policy in Australia", Public Understanding of Science 12(4): 381-401. 
Epstein, S. (1996) Impure science: AIDS, activism, and the politics of knowledge. Berkeley: University of California Press.

Evans, R. and Plows, A. (2007) "Listening without prejudice?: Re-discovering the value of the disinterested citizen", Social Studies of Science 37(6): 827-53.

Felt, U., et al. (2009) "Unruly ethics: On the difficulties of a bottom-up approach to ethics in the field of genomics", Public Understanding of Science 18(3): 35471.

Genus, A. and Rogers-Hayden, T. (2005) "Genetic engineering in Aotearoa, New Zealand: A case of opening up or closing down debate?" in Science and citizens: Globalization and the challenge of engagement, edited by M. Leach, I. Scoones and B. Wynne London: Zed Books.

Gieryn, T.F. (1982) "Relativist/constructivist programmes in the sociology of science: Redundance and retreat", Social Studies of Science 12(2): 279-97.

Gilbert, N.G. and Mulkay, M. (1984) Opening Pandora's box: A sociological analysis of scientists' discourse. London: Cambridge University Press.

Gobo, G. (2004) "Sampling, representativeness and generalizability" in Qualitative research practice, edited by C. Seale, G. Gobo, J. F. Gubrium and D. Silverman London: Sage.

Goven, J. (2006) "Processes of inclusion, cultures of calculation, structures of power; scientific citizenship and the royal commission on genetic modification", Science, Technology, \& Human Values 31(5): 565-98.

Hagendijk, R. and Irwin, A. (2006) "Public deliberation and governance: Engaging with science and technology in contemporary Europe", Minerva 44(2): 16784.

Harvey, O. (2005) "Regulating stem-cell research and human cloning in an Australian context: An exercise in protecting the status of the human subject", New Genetics \& Society 24(2): 125-36.

Harvey, O. (2008) "Regulating stem cell research and human cloning in an Australian context: The Lockhart Review", New Genetics and Society 27(1): 33-42.

Hauskeller, C. (2005) "The language of stem cell science" in Crossing borders. Grenzüberschreitungen. Ethische, politische und religiöse kontexte der stammzellforschung., edited by W. Bender, C. Hauskeller and A. Manzei Münster: Agenda Verlag.

Horst, M. (2007) "Public expectations of gene therapy: Scientific futures and their performative effects on scientific citizenship", Science, Technology, \& Human Values 32(2): 150-71.

Inquiry into legislative responses to recommendations of the Lockhart Review (2006) Submissions received by the committee.

http://www.aph.gov.au/senate/committee/clac_ctte/completed_inquiries/200407/leg_response_lockhart_review/submissions/sublist.htm [last accessed 28 August 2011].

Irwin, A. (1995) Citizen science: A study of people, expertise and sustainable development. London: Routledge. 
Irwin, A. (2001) "Constructing the scientific citizen: Science and democracy in the biosciences", Public Understanding of Science 10(1): 1-18.

Irwin, A. (2006) "The politics of talk: Coming to terms with the 'new' scientific governance", Social Studies of Science 36(2): 299-320.

Irwin, A. and Wynne, B., Eds (1996). Misunderstanding science? The public reconstruction of science and technology. Cambridge: Cambridge University Press.

ISSCR (2004) Nomenclature statement. September 2nd, 2004 http://www.isscr.org/press_releases/nomenclature_statement.doc [last accessed 13 August 2007].

Katz, E., et al. (2009) "Evolving scientific research governance in Australia: A case study of engaging interested publics in nanotechnology research", Public Understanding of Science 18(5): 531-45.

Kerr, A., Cunningham-Burley, S. and Amos, A. (1997) "The new genetics: Professionals' discursive boundaries", The Sociological Review 45(2): 279303.

Kerr, A., Cunningham-Burley, S. and Amos, A. (1998) "Drawing the line: An analysis of lay people's discussions about the new genetics", Public Understanding of Science 7(2): 113-33.

Kerr, A., Cunningham-Burley, S. and Tutton, R. (2007) "Shifting subject positions: Experts and lay people in public dialogue", Social Studies of Science 37(3): 385-411.

Kitzinger, J. and Williams, C. (2005) "Forecasting science futures: Legitimising hope and calming fears in the embryo stem cell debate", Social Science \& Medicine 61(3): 731-40.

Kurath, M. and Gisler, P. (2009) "Informing, involving or engaging? Science communication, in the ages of atom-, bio- and nanotechnology", Public Understanding of Science 18(5): 559-73.

Levinson, S.C. (1983) Pragmatics. Cambridge: Cambridge University Press.

Lezaun, J. and Soneryd, L. (2007) "Consulting citizens: Technologies of elicitation and the mobility of publics", Public Understanding of Science 16(3): 279-97.

Lovell, T. (2003) "Resisting with authority: Historical specificity, agency and the performative self", Theory, Culture \& Society 20(1): 1-17.

Lysaght, T. and Kerridge, I.H. (2010) "Rhetoric, power and legitimacy: A critical analysis of the public policy disputes surrounding stem cell research in Australia (2005-6)", Public Understanding of Science 1: 1-16.

Marks, N.J. (2008). Opening up spaces for reflexivity? Scientists' discourses about stem cell research and public engagement. Unpublished $\mathrm{PhD}$ thesis, University of Edinburgh.

Mey, J.L. (2001) Pragmatics, 2nd edition. Malden, MA: Blackwell Publishing.

Michael, M. and Brown, N. (2000) "From the representation of publics to the performance of 'lay political science'", Social Epistemology 14(1): 3-19. 
Mulkay, M. (1994) "The triumph of the pre-embryo: Interpretations of the human embryo in parliamentary debate over embryo research", Social Studies of Science 24(4): 611-39.

Mulkay, M. (1996) "Frankenstein and the debate over embryo research", Science, Technology, \& Human Values 21(2): 157-76.

Nelkin, D. (1975) "The political impact of technical expertise", Social Studies of Science 5(1): 35-54.

Official Committee Hansard; Senate Standing Committee on Community Affairs; Canberra 20 October (2006) Reference: Legislative responses to the lockhart review. http://www.aph.gov.au/hansard/senate/commttee/S9809.pdf [last accessed 4 February 2011].

Official Committee Hansard; Senate Standing Committee on Community Affairs; Melbourne 24 October (2006) Reference: Legislative responses to the lockhart review. http://www.aph.gov.au/hansard/senate/commttee/S9811.pdf [last accessed 4 February 2011].

Official Committee Hansard; Senate Standing Committee on Community Affairs; Sydney 23 October (2006) Reference: Legislative responses to the lockhart review. http://www.aph.gov.au/hansard/senate/commttee/S9810.pdf [last accessed 4 February 2011].

Parry, S. (2003) "The politics of cloning: Mapping the rhetorical convergence of embryos and stem cells in parliamentary debates", New Genetics and Society 22(2): 177-200.

Parry, S. (2009) "Stem cell scientists' discursive strategies for cognitive authority", Science as Culture 18(1): 89-114.

Potter, J. and Mulkay, M. (1985) "Scientists' interview talk: Interviews as a technique for revealing participants' interpretative practices" in The research interview. Uses and approaches, edited by M. Brenner, J. Brown and D. Canter London: Academic press.

Prohibition of Human Cloning Act (2002). Canberra: The Parliament of the Commonwealth of Australia.

Prohibition of Human Cloning for Reproduction and the Regulation of Human Embryo Research Amendment Act (2006). Canberra: The Parliament of the Commonwealth of Australia.

Research Involving Human Embryos Act (2002). Canberra: The Parliament of the Commonwealth of Australia.

Robins, R. (2001) "Overburdening risk: Policy frameworks and the public uptake of gene technology", Public Understanding of Science 10(1): 19-36.

Robins, R. (2005) "Biomedical innovation or bioethical precaution: The stem cell debate in Australia" in Crossing borders. Grenzüberschreitungen, edited by C. Hauskeller, W. Bender and A. Manzei Munster: Agenda Verlag.

Rubin, B.P. (2008) "Therapeutic promise in the discourse of human embryonic stem cell research", Science as Culture 17(1): 13-27. 
Schibeci, R. and Harwood, J. (2007) "Stimulating authentic community involvement in biotechnology policy in Australia", Public Understanding of Science 16(2): 245-55.

Scott, A. and Du Plessis, R. (2008) "Eliciting situated knowledges about new technologies", Public Understanding of Science 17(1): 105-19.

Searle, J.R. (1968) "Austin on locutionary and illocutionary acts", The Philosophical Review 77(4): 405-24.

Searle, J.R. (1969) Speech acts: An essay in the philosophy of language London: Cambridge University Press.

Streek, J. (1980) "Speech acts in interaction: A critique of searle", Discourse Processes 3(133-54).

Szerszynski, B. (1999) "Risk and trust: The performative dimension", Environmental Values 8(2): 239-52.

Wood, T. (2011) "Hermeneutic pragmatics and the pitfalls of the normative imagination", Journal of Pragmatics 43(1): 136-49.

Wright, N. and Nerlich, B. (2006) "Use of the deficit model in a shared culture of argumentation: The case of foot and mouth science", Public Understanding of Science 15(3): 331-42

Wynne, B. (2005) "Risk as globalizing 'democratic' discourse? Framing subjects and citizens" in Science and citizens: Globalization and the challenge of engagement, edited by M. Leach, I. Scoones and B. Wynne London: Zed Books.

Young, N. and Matthews, R. (2007) "Experts' understanding of the public: Knowledge control in a risk controversy", Public Understanding of Science 16(2): 123-44. 